\title{
The Testimony of the Private and the Public in the Time of Socialism
}

Rastko JOVIC*

Abstract: Few days after the death of Joseph Broz Tito, communist leader of Yugoslavia, in May 1980, my father has been taken into custody, then questioned put on the trial and convicted for six years on the political accusations. His active service as an Orthodox priest terminated that May 1980. Being moved from one police station to another, from one city to another, he left behind two young children and a woman with no income. In such an awkward situation, the police offered him cooperation with the state and the party, i.e., to sign an already written confession. After the fall of communism, he became recognized as a martyr of the Church, like many similar cases. The problem with communism was that it paradoxically worked for the Church. By his brutality, communism produced saints and martyrs for the Church. In today's world of political correctness, however, there are no martyrs and saints, and moral differences are less apparent. The article explores the historical situation during communism in Yugoslavia. Simultaneously, this paper tries to explain the Church mentality during those years and whether they still affect us today.

Keywords: martyrdom, socialism, Church, consciousness, priest, public space.

\section{Introduction}

In this article, I tried to combine one personal story together with a general historical overview that draws a picture of

* Associate Professor at Faculty of Orthodox Theology, University of Belgrade, Serbia. 
martyrdom, which the Serbian Orthodox Church (SOC) experienced in socialist Yugoslavia. The problem with communism was that it paradoxically worked for the Church. That historical period brought a clear ethical distinction between good and evil. At that time, the Church wanted to acquire more social relevance, simultaneously trying physically to survive. Several decades under the socialist yoke, obviously affected the mentality of the Church's self-consciousness. The Church internalized and self-enclosed most of the time. That could explain today's observable behavior of the Church, and that is often fear from modernity. Theologians need to evaluate this period of socialism, to understand the Church and theology from that period. It is time to assess this period so that we can draw conclusions for our future. Different times need a different approach to the Church's self-consciousness and our understanding of the society in which we live today. We would need to take seriously into consideration the communist period for further self-understanding.

\section{Privately about Socialism}

Few days after the death of Josip Broz Tito, the communist leader of Yugoslavia, in May 1980, my father ${ }^{1}$ has been arrested, interrogated, and then put on trial and convicted. At the time when this happened, he was already an Orthodox priest in a small village in Bosnia (one of six socialist republics in Yugoslavia). At the first moment, he has not been arrested immediately, but he has been called up for a military exercise. Instead of going to the mentioned exercise, he was taken to the Secretary of Interior Affairs (SIA) for questioning and later arrested. Transferred from one police building to another, from one city to another, he left behind two small children and a woman with no income. In such a problematic situation, the security service offered him cooperation, i.e., they asked him to sign the confession that has

${ }^{1}$ Savo B. Jovic (born in 1954), Orthodox priest which today serves in Belgrade also as a Secretary of the Holy Synod SOC. 
The Testimony of the Private and the Public

in the Time of Socialism

already been written in advance. In this confession letter, he needed to accept his guilt for working against socialism, against the brotherhood of ethnicities within Yugoslavia as well as he will promise to promote socialism and defend it. He did not sign anything, being confused about why he is arrested in the first place. Only 26 years old, he found himself like the main character in Kafka's Trial.

For my father personally, this was not an easy thing. He was quite young, only being a priest for four years. During interrogation, he is deprived of sleep and proper food, knowing that he left behind a wife and two children of 21 months and four months old. At the same time, he has threatened with six years of prison, according to the law. At that time, verbally accusing and attacking socialism could give you from 1-6 years in jail (the great article 133. in the Criminal Code of Yugoslavia). Despite being psychologically tortured and physically abused during the process of interrogation, he decides not to sign any confession. Only after hours and hours of talking, police finally explained to him why he had been arrested. They charged him for one letter that he allegedly sent to the Municipal Committee of the Communist Party of a small city near his birth village.

The letter has been signed by the "Serbian People's Movement of Northeast Bosnia" 2 . The message called upon those Serbian members of the Communist Party to understand the uncertain status of Serbian people in Yugoslavia. Soon, during the interrogation, the police informed my father that after professional checking of the manuscript, they found out that he really did not write the letter. However, instead, to be liberated after this discovery, police now did one step further, accusing him of dictating and inspiring the message. In the eyes of the authorities, that is much worse. Without signed confession and promise to cooperate with the government, he has been put on the trial.

At the trial in the city of Tuzla, it has been revealed openly that many witnesses lied, not knowing to answer some simple

${ }^{2}$ Savo B. Jovic, Andjeli zverinje kuce, Beograd, Pravoslavna rec, 2012, p. 30. 
questions of the criminal defense lawyer. Those present at the Court believed that my father will be released for the lack of any proof. The judge decided to sentence him 6 years in prison. In late November 1984, some days before the Day of the Republic ${ }^{3}$, he was pardoned after serving almost five years in prison ${ }^{4}$. After serving his prison sentence in the famous Zenica Penitentiary ${ }^{5}$, he returned to the village (Obudovac), where he was arrested. Remaining there as a parish priest for another two and a half years. But even after serving his sentence, authorities threatened him to move from the village somewhere else. Simple people in the community did not believe that my father was guilty. After his return from prison, he became some kind of hero for local parishioners but also many anti-communists nearby. That put even more pressure on him by the local communist officials to leave as soon as possible. After more than two years, he decided to move from Bosnia to Serbia in early August 1987.

When my father was arrested, I was 21 months old and could not comprehend what was happening and why. Still, I remember that during one visit to the prison, they forbade me to hug my father. When my father saw me, he wanted to take me in the arms and hug me. Instead, the policeman separated us with a truncheon and said that it was forbidden. I remember that I cried and that my father canceled the visit out of protest. Later on, when he decided to move to Serbia in 1987, I didn't understand why we are doing it. Many years later, it was finally revealed to me. To eventually force my father to leave the village as an "enemy of the state", some communist officials decided to arrange the "truck accident". The plan was to hit me on my way to school by truck. That would be considered an accident, but it would put a strong message to my family. Father did not wait for the beginning of the new school year in September 1987, we already left our village in August.

\footnotetext{
${ }^{3}$ Official holiday in Yugoslavia, celebrated on $29^{\text {th }}$ November.

${ }^{4}$ More on the arrest: Savo B. Jovic, Andjeli zverinje kuce, Beograd, Pravoslavna rec, 2012.

${ }^{5}$ Zenica had penitentiary from time of Austro-Hungarian Empire.
} 
The Testimony of the Private and the Public in the Time of Socialism

\section{Martyrdom}

Comparing the time of communism and today's era, we can easily conclude that social persecution continues by new governments, only with new and more modern means ${ }^{6}$. The communists consciously or unconsciously created martyrs and saints, with whom they filled our Church calendars. The misfortunes of the families that suffered persecution were compensated, at least in part, through some kind of social satisfaction and church recognition of their torture. That was precisely the model of the Church's struggle with communism. Through the persecution, the Church named new saints and martyrs, showing the eternal victory of persecuted over the perpetrators. In today's world, it is challenging to be a martyr and even harder to be a saint. Persecutions are carried out through the mass media, and the accusations are so varied, sometimes unreal $^{7}$. Even worse, if you oppose the mainstream thinking, you will be put through the wrath of the modern mass media. After being incriminated through them, a person has no desire to defend himself, much less a "chance" to become a martyr. After being despised by social media, a more common choice is to wish you didn't exist at all. That is the victory of today's new social setting, i.e., the abolishment of the possibility of distinguishing between good and evil. The more you're trying to escape it, the more you're in. In a great Polish movie "Kler" (2018), it has been well portrayed what martyrdom could be in today's world. Suffering and even battle for a better society in the modern era transform into nothing more than an Instagram event, i.e., something that lasts for a few hours.

${ }^{6}$ Douglas Murray, The Madness of Crowds: Gender, Race and Identity, London, Oxford, New York, New Delhi, Sydney, Bloomsbury Continuum, 2019.

7 For more: Douglas MurRAY, The Madness of Crowds: Gender, Race and Identity, London, Oxford, New York, New Delhi, Sydney, Bloomsbury Continuum, 2019. 
This is not an apology for socialism, but it is a relief for me personally. Until yesterday I was angry or resentful for my father, who was not for me in my formative years. Today at least I understand his courage much better. It was his desire to leave the mark in history, bold, and firm to inspire people around him. Something that today is much less conceivable to be attained.

\section{Being a Priest after WWII}

For most of the $20^{\text {th }}$ century, the Orthodox Church in Yugoslavia has been concerned with existential survival. During WWII, losses in the clergy became almost irreparable ${ }^{8}$, which period of socialism only intensified ${ }^{9}$. After World War II, one priest cared for 4,100 people, and by 1963 that number had doubled ${ }^{10}$. Also, in the last one hundred years, Serbia had nine war conflicts from which the most tragic one was the First World War in which Serbia lost more than $25 \%$ of its population ${ }^{11}$. After the Second World War, communism overtook the state being harsh, especially to the Serbian Orthodox Church (SOC). After 1945, the Church has been violently pushed into the privacy of someone's household with no right for a broader relevance. That was the primary goal of persecution, which was the harshest from 1945-1960 but continued silently until 1989.

During WWII, around 600 priests and monks were expelled from their parishes, and almost 650 were killed. Over 1,000 churches and monasteries were looted and destroyed. "Material and cultural-historical damage is invaluable. Serbian Orthodoxy is almost destroyed"12. End of WWII, the Serbian Church faced with

${ }^{8}$ Spomenica pravoslavnih svestenika 1941-1945, Beograd, 1960.

9 Savo B. Jovic, Utamnicena crkva: stradanje svestenstva Srpske Pravoslavne Crkve od 1945-1985, Beograd, Pravoslavna rec, 2012.

10 Dragan SLJIVIC, "Orthodoxy and Politics in Serbia“, in Jelena Jablanov, Maksimovic, Andrijana KRSTIC (eds.), Church in a Pluralistic Society, Belgrade, Konrad Adenauer Foundation, Christian Cultural Center, 2009, p. 79.

${ }^{11}$ Kosta NiKOLIC, Jedna izgubljena istorija - Srbija u 20. veku, Beograd, Sluzbeni glasnik, 2016, p. 375.

${ }^{12}$ Ljubodrag Dimic, Serbs and Yugoslavia, Belgrade, Stubovi kulture, 1998, p. 87. 
The Testimony of the Private and the Public in the Time of Socialism

fewer bishops, and twelve bishops no longer managed their dioceses ${ }^{13}$. The Serbian Patriarch was imprisoned in Dachau and returned to Yugoslavia in $1946^{14}$. The Bishop of Dalmatia, Dr. Irinej Djordjevic, was interned in Italy, and the Bishop of Raska and Prizren, Serafim Jovanovic, was interned in Tirana, where he died (†1945). Metropolitan Josif of Skopje and Bishop Vikentije (Prodanov) of Zletovo-Strumica were expelled from their dioceses. Metropolitan Dositej of Zagreb was tortured by the Ustashas ${ }^{15}$ (Croatian fascists) and sent back to Serbia completely mentally broken. The Bishop of Srem, Valerijan Pribićević, was also ill. Fleeing from the terror of the Ustashas, Bishop Nektarije Krulj of Zvornik and Tuzla and Nikolaj Jokanović of Zahumlje and Herzegovina $(\uparrow 1943)$ took refuge in Serbia. Metropolitan of DabroBosanska Petar Zimonjic, Bishop of Gornji Karlovac Sava Trlajic, and Bishop of Banja Luka Platon Jovanovic were tortured and then killed by Ustasha. Bishop Vladimir Rajić had to leave the diocese of Mukachevo-Prjaševo, and the bishop of Czechoslovakia-Moravia Gorazd was murdered by the Germans. In Montenegro, Metropolitan Joanikije Lipovac was executed by the new authorities, and his grave is still unknown ${ }^{16}$.

There were only seven bishops in the country who resided in their dioceses. There were more than eighty priests in prisons, sentenced to long sentences, while some were arrested without a conviction and kept in prisons. The social security of the priests was abolished, and the law on agrarian reform confiscated 70,000 hectares of arable land and forests from the Church and

${ }^{13}$ Djoko SLIJEPCEVIC, Istorija Srpske pravoslavne Crkve 3, Beograd, BIGZ, 1991, p. 194.

${ }^{14}$ Rastko Jovic, "Patriarch Gavrilo Dozic and Ideal of Freedom. Yugoslavia: Coup D'etat In 1941" in Astra Salvensis, 11/2018, p. 159-167.

15 Ustasha, was a Croatian fascist, ultranationalist and terrorist organization (19291945). Its members murdered hundreds of thousands of Serbs, Jews, and Roma as well as political dissidents in Yugoslavia during WWII. Ustasha founder Dr. Ante Pavelic later became the leader of Independent State of Croatia (19411945).

${ }^{16}$ Djoko SLIJEPCEVIC, Istorija Srpske pravoslavne Crkve 3, Beograd, BIGZ, 1991, p. 194-195. 
nationalized 1,180 buildings. Many episcopal residences were confiscated (Vrsac, Zajecar, Sabac, Pozarevac, Niksic, Tuzla, Sibenik, Novi Sad). Local authorities in many parts of the country forbade priests to perform funerals, baptisms, and weddings. The demolition of churches and monasteries was a common occurrence $^{17}$.

Also, secessionist movements wanted to tear apart the Serbian Orthodox Church. Those separatist moves have been fueled by the socialist government appearing in Montenegro, Croatia, and Macedonia ${ }^{18}$. The process of atheization in the period 1945-1960 increased. During this period, "the number of Orthodox bishops was reduced by $33 \%$, priests by $50 \%$ (there are only 1,800$)$, Seminaries by $60 \%$, the number of students attending Orthodox schools by $75 \%$, the Church land ownership was only $12 \%$ of the one before WWII"19. Faculty of Orthodox Theology in Belgrade was banned from the University, many priests arrested, murdered, or recruited for a new government ${ }^{20}$. Religious Education had been expelled from the school curricula in 1952. The Church withdrew into the private sphere after WWII. With the implemented repressive measures that put it on the margins of society, the Church in socialist Yugoslavia was left to die out, but more importantly - subjected to strict regime control ${ }^{21}$. It is estimated that in the period 1945-1985, the Serbian Orthodox Church lost 500 priests, killed and imprisoned ${ }^{22}$. As the socialist state was responsible for the totality of social activities, the Church was almost completely limited, disapproved, and

${ }^{17}$ Dragoljub R. Zivojinovic, Serbian Orthodox Church and the New Government 1944-1950, Srbinje- Belgrade-Valjevo-Munich, Hriscanska misao, 1998, p. 94.

${ }^{18}$ Ibidem, p. 119.

${ }^{19}$ Ljubodrag Dimic, Serbs and Yugoslavia, Belgrade, Stubovi kulture, 1998, p. 87.

${ }^{20}$ Radmila RADIC, "O nekim metodama delovanja Sluzbe bezbednosti u verskim zajednicama do polovine 60-ih godina 20. veka" in Radomir Popovic (ed.), Srpska teologija danas 2012, Beograd, PBF ITI, 2013, p. 52-66.

${ }^{21}$ Radmila RADIC, Drzava i verske zajednice 1945-1970 I-II, Beograd, INIS, 2002.

${ }^{22}$ Savo B. Jovic, Utamnicena crkva: stradanje svestenstva Srpske Pravoslavne Crkve od 1945-1985, Beograd, Pravoslavna rec, 2012. 
The Testimony of the Private and the Public in the Time of Socialism

ultimately sanctioned for most of the humanitarian work. In such a dead end, the only thing left for the Church was to turn into herself; self-enclosure.

In most of history, the Serbian Orthodox Church coped with political interferences. During socialism, this became even more vivid for the reason that the government hastened to confront with Her. The clergy was under the firm control of the state, exercised through the Priest' Associations ${ }^{23}$. The state also did not recognize Church Seminaries as high schools, and the system in the Seminary itself implied a five-year cycle of education. After the fourth year of theology, the students of this school needed to serve their military service. Recruitment for cooperation with state security began right there. It ended with the return to the fifth grade of Seminary. The purpose of all this was to neutralize the Church as a social institution of any importance. The government wanted to see SOC as a protector of the regime and the tool to denunciate "the enemies." Church paid a high toll struggling to resist the authorities.

\section{Excluding from the Society}

Turbulent times in the late ' $80 \mathrm{~s}$ found the Church completely unprepared to enter into the public space because events of great historical importance changed too quickly. The fall of the Berlin Wall and the collapse of Soviet bloc came too surprisingly. It was a great shock for all of those who participated in this process. Even more for the world who watched these vast changes. After years of silence and non-participation in public life, the Church was not ready to address the wider society. Events unfolded quickly with a full force of destruction. ${ }^{24}$ The Serbian Orthodox Church found Herself unprepared for what was coming,

${ }^{23}$ State government used the Priest Association in order to control the Church. For more: Radmila RADIC, Momcilo MitroviC (eds.), Zapisnici sa sednica: Komisija za verska pitanja NR/SR Srbije 1945-1978, Beograd, INIS, 2012.

${ }^{24}$ Rastko JovIC, Dinamika hriscanskog identiteta, Beograd, PBF ITI, 2018, p. 99108. 
and Her actions seemed unplanned, without a clear strategy ${ }^{25}$ and the necessary professional staff within Her own ranks. This proved the necessity to engage professionals who could be outside the Church borders.

It seems that the last two decades (2000-2020) provided an opportunity for the Church in Serbia to integrate into the currents of public action with an apparent and profiled attitude. The number of students and candidates in the Seminaries has been almost completely renewed in the Serbian Orthodox Church (SOC). Introduction of Religious Education in primary and secondary schools in 2001, allowed SOC to acquire a piece of public importance. For the first time after 1952, SOC has been allowed to express Her public role within the conventional educational system. That was of central importance for the Church to exercise Her mission and significance.

When the civil war broke out in Yugoslavia (1991), political circumstances deteriorated quickly. This culminated even more after the bombardment of Serbia in 1999, by NATO. The subsequent declaration of Kosovo independence in 2008 made things worse. After decades of silence and isolation, the Church was not ready for what was coming: wars, sanctions, destruction of the country, extreme poverty, refugees, and new political figures.

Today we are talking about the desecularized world ${ }^{26}$ in which to be religious does not imply belonging to any institution. Some authors believe that we cannot speak about desecularization but rather about religious renewal, which is a more appropriate term after the fall of communism ${ }^{27}$. The return of religiosity only speaks of man's hunger for the sanctity. It is

25 Milorad Tomanić, Srpska crkva u ratu $i$ ratovi u njoj, Beograd, Medijska knjizara Krug, 2001.

${ }^{26}$ Peter L. BERGER (ed.), The Desecularization of the World: Resurgent Religion and World Politics, Grand Rapids, William B. Eerdmans, 1999.

27 Sergej FLERE, "Mogucnosti sociologije u predvidjanju sudbine hriscanstva", in Hriscanstvo u 21. veku, ed. Dragoljub B. Đorđević, Predrag Stajić, Dragan Todorović, Novi Sad, Leskovac, Niš, Prometej, Leskovački kulturni centar, JUNIR, 2014, p. 111. 
The Testimony of the Private and the Public in the Time of Socialism

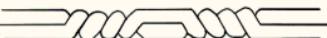

quite a different question in which way this return to religiosity will be expressed. Usually and most often, the religious renewal will not be through the religious institutions. Still, it is more open up for different possibilities and various manifestations. In such a new situation, it becomes a challenge for the Church to acquire freedom in a public space. It is even more challenging to be ready for the responsibility that such freedom entails ${ }^{28}$.

\section{Theology and Public Relevance}

At the time of communism, Church has been forced to exclude Herself from any active role within society, reduced to the religious customs. A specific attempt by the Church to prove herself important and essential became necessary. One example of this in Yugoslavia was ethno-theology, which has proven to be a defense of the human right of free speech. At the trial of my father, one of the first questions of the judge was, how he dares to question the issue of national equality in Yugoslavia. He examined civic equality through a straightforward matter of representation of the Cyrillic alphabet in public usage ${ }^{29}$. The lack of possibility to use the Cyrillic alphabet, which was mainly the marker of the Serbian distinctiveness, proves the identity troubles. In Yugoslavia, at the time, some nationalisms were positive and some negative ${ }^{30}$. The Serbian one has been declared as a negative one that needs suppression.

${ }^{28}$ To find more on religiosity in Serbia: Religioznost $u$ Srbiji 2010: Istrazivanje religioznosti građana Srbije $i$ njihovog stava prema procesu evropskih integracija, Beograd, Fondacija Konrad Adenauer, Hriscanski kulturni centar, Centre for European Studies, 2011, p. 201-253. Also, [Post]sekularni obrt: religijske, moralne $i$ društveno-političke vrednosti studenata u Srbiji, ed. Mirko Blagojevic, Jelena Jablanov Maksimovic, Tijana Bajovic, Beograd, Centre for European Studies, Konrad Adenauer Stiftung, Institut za filozofiju i društvenu teoriju, 2013.

${ }^{29}$ Savo B. Jovic, Andjeli zverinje kuce, Beograd, Pravoslavna rec, 2012, p. 65-66

${ }^{30}$ Dejan Jovic, Jugoslavija, drzava koja je odumrla: Uspon, kriza i pad Kardeljeve Jugoslavije (1974-1990), Zagreb, Prometej, 2003. 
At the same time, folk customs often seemed more pagan and less Christian. In their origin, they could not express the Christian life without proper interpretation. Therefore, they acquired a taste of something against which the Church had fought for a long time. However, the contexts have changed. Long slavery under the Turks, feudalism, the authoritarian system of communism, and later authoritarian governments did not enable a peaceful transition to a democratic order for the Church. Being forced on the edge of society, the Church embraced even more folk customs as an essential social tool. Customs enabled the Church to be present within the community, especially in the situation where SOC lacked church buildings and, consequently, the means to perform the Liturgy ${ }^{31}$. Self-enclosure, which lasted for several decades, accentuated the need for customs. Their importance for the Church survival changed Her mentality, causing distrust in the modern world ${ }^{32}$. In the time of communism, through ethnotheology $y^{33}$, the Church tried to prove itself significant in society by talking about something that was almost forbidden. The Church's struggle for the expression of officially undesirable national identity, a Serbian one, could be equated with the struggle for human rights (freedom of speech) ${ }^{34}$. Ethno-theology was an avant-garde phenomenon comparing to the official ideology of socialism and internationalism in Yugoslavia. Paradoxically, the struggle for national rights could be equated with a battle for human rights during the communist dictatorship.

31 They have been destroyed during Ottoman rule, than WWI, WWII and during the communist period.

32 Radovan Bigovic, Crkva i drustvo, Beograd, Hilandarski fond, 2000, p. 261262.

${ }^{33}$ Rastko Jovic, "Theology with a Human Face", in Journal of Eastern Christian Studies, 69 (1-4)/ 2017, p. 167-180.

34 Rastko Jovic, "Hriscanska kultura subverzivnosti" in Religijska kultura, ed. Dragoljub B. Djordjevic, Leskovac, Leskovacki kulturni centar, 2015, p. 132156. 


\section{Epilogue}

The problem with communism was that it paradoxically worked for the Church. Being brutal, the communist regime actually created saints and martyrs for the Church. This clearly maintained the ethical distinction between good and evil. During this period, the boundaries between "them and us" were evident. Saint John the Ladder once said, "It is good to forgive, it is better to forget." At the same time, in the modern world, digital memory does not allow forgetting. This leads to the impossibility of forgiveness and reconciliation within society. The statements of individuals are repeated and condemned even after 30 years, although the author could publicly denounce his/her speech.

Life is one big theatrical play, and almost all of those who persecuted and judged my father, i.e., protectors of internationalism and socialism during the civil war in Bosnia (1992-1995), suddenly became a "great" nationalists. They suddenly turned their views upside down, becoming the protectors of Serbian national identity from the "evil" communists and the nationalisms of the others with whom they lived together in SFRY. It seems that the civil wars in Yugoslavia have been a natural consequence of the schizophrenia within the system, i.e., within the consciousness of the same people who build socialism and then fought against it. Almost the same people that during the '80s fought against the enemies of socialism soon reversed their goals. At the beginning of the " $90 \mathrm{~s}$, they continued their battles, but now with "sympathizers of socialism," respectively. At the beginning of the $21^{\text {st }}$ century, the same individuals became EU fanatics. In our post-socialist society, schizophrenia continues to be expressed through some new wars, and even cultural ones. These dangerous and fierce social upheavals are coming to confront the Church again and again.

The fluid and turbulent history influenced the mentality, the Church's role and position in such an environment. Although 
SOC cannot contribute to the progress of science, either is it our task to do so; nevertheless, She could be able to provide and facilitate development in the quality of human relationships, i.e., to heal schizophrenia in one society. Our theological framework of the Body of Christ as Church - community - means much effort to help people to re-establish their broken relationships in fighting against alienation. Therefore, in addition to social work, it is necessary to preserve and retain a prophetic voice against systematic injustice. In terms of self-consciousness, the Church needs to lead towards the emancipation of faith. This can deliver Her from the yoke of self-isolation and social disability in the future.

$\cos 8$

\section{Bibliography}

1. *** [Post]sekularni obrt: religijske, moralne i društveno-političke vrednosti studenata $u$ Srbiji, ed. Mirko Blagojevic, Jelena Jablanov Maksimovic, Tijana Bajovic, Beograd, Centre for European Studies, Konrad Adenauer Stiftung, Institut za filozofiju i društvenu teoriju, 2013.

2. *** Religioznost u Srbiji 2010: Istrazivanje religioznosti građana Srbije $i$ njihovog stava prema procesu evropskih integracija, Beograd, Fondacija Konrad Adenauer, Hriscanski kulturni centar, Centre for European Studies, 2011.

3. BERGER, Peter L. (ed.), The Desecularization of the World: Resurgent Religion and World Politics, Grand Rapids, William B. Eerdmans, 1999.

4. BIGOvic, Radovan, Crkva i drustvo, Beograd, Hilandarski fond, 2000.

5. DIMIC, Ljubodrag, Serbs and Yugoslavia, Belgrade, Stubovi kulture, 1998.

6. DIMIC, Ljubodrag, Serbs and Yugoslavia, Belgrade, Stubovi kulture, 1998.

7. FLERE, Sergej, "Mogucnosti sociologije u predvidjanju sudbine hriscanstva", in Hriscanstvo u 21. veku, ed. Dragoljub B. Đorđević, Predrag Stajić, Dragan Todorović, Novi Sad, 
The Testimony of the Private and the Public in the Time of Socialism

Leskovac, Niš, Prometej, Leskovački kulturni centar, JUNIR, 2014.

8. Jovic, Dejan, Jugoslavija, drzava koja je odumrla: Uspon, kriza $i$ pad Kardeljeve Jugoslavije (1974-1990), Zagreb, Prometej, 2003.

9. JovIC, Rastko, "Hriscanska kultura subverzivnosti" in Religijska kultura, ed. Dragoljub B. Djordjevic, Leskovac, Leskovacki kulturni centar, 2015.

10. IDEM, "Patriarch Gavrilo Dozic and Ideal of Freedom. Yugoslavia: Coup D'etat In 1941" in Astra Salvensis, 11/2018.

11. IDEM, "Theology with a Human Face", in Journal of Eastern Christian Studies, 69 (1-4)/ 2017.

12. IDEM, Dinamika hriscanskog identiteta, Beograd, PBF ITI, 2018.

13. Jovic, Savo B., Andjeli zverinje kuce, Beograd, Pravoslavna rec, 2012.

14. IDEM, Andjeli zverinje kuce, Beograd, Pravoslavna rec, 2012.

15. IDEM, Utamnicena crkva: stradanje svestenstva Srpske Pravoslavne Crkve od 1945-1985, Beograd, Pravoslavna rec, 2012.

16. IDEM, Utamnicena crkva: stradanje svestenstva Srpske Pravoslavne Crkve od 1945-1985, Beograd, Pravoslavna rec, 2012.

17. Murray, Douglas, The Madness of Crowds: Gender, Race and Identity, London, Oxford, New York, New Delhi, Sydney, Bloomsbury Continuum, 2019.

18. NiKOLIC, Kosta, Jedna izgubljena istorija - Srbija u 20. veku, Beograd, Sluzbeni glasnik, 2016.

19. RADIC, Radmila, "O nekim metodama delovanja Sluzbe bezbednosti u verskim zajednicama do polovine 60-ih godina 20 . veka" in Radomir PoPOVIC (ed.), Srpska teologija danas 2012, Beograd, PBF ITI, 2013.

20. RADIC, Radmila, Drzava $i$ verske zajednice 1945-1970 I-II, Beograd, INIS, 2002.

21. IDEM, Momcilo MITROVIC (eds.), Zapisnici sa sednica: Komisija za verska pitanja NR/SR Srbije 1945-1978, Beograd, INIS, 2012.

22. SLIJEPCEVIC, Djoko, Istorija Srpske pravoslavne Crkve 3, Beograd, BIGZ, 1991.

23. SlJiviC, Dragan, "Orthodoxy and Politics in Serbia“, in Jelena JABLANOV, Maksimovic, Andrijana KRSTIC (eds.), Church in a 
Rastko JOVIC

Pluralistic Society, Belgrade, Konrad Adenauer Foundation, Christian Cultural Center, 2009.

24. Tomanić, Milorad, Srpska crkva u ratu i ratovi u njoj, Beograd, Medijska knjizara Krug, 2001.

25. ZivojInOvic, Dragoljub R., Serbian Orthodox Church and the New Government 1944-1950, Srbinje- Belgrade-Valjevo-Munich, Hriscanska misao, 1998. 